\title{
CINDERELLAGAME BY PAUL-EERIK RUMMO AS COMPARED TO SONG GAMES
}

\section{Harri Mürk}

Estonians are ardent theatre-goers. The dozen professional theatre companies in a small country with population scarcely a million, and the numerous amateur groups both st home and until recent years also in the Diaspora refer to the popularity of organised theatre. Despite the keen public support to theatre, very little of significant merit has emerged in original native Estonian dramaturgy. The situation with prose writing and poetry is quite the opposite for since the appearance of the first original Estonian belleslettres, many prose writers and poets, both male and female, have proven themselves as world class writers. The most recent example of this is Jaan Kross with his meteoric rise to the international renown.

According to the opinion of the author of the present article, among the very few original Estonian plays that can claim to be of international stature, Cinderellagame (Tuhkatriinumäng, 1969) by PaulEerik Rummo should be regarded as one of the truly outstanding works in Estonian dramaturgy. In the following essay, I will briefly analyse one of the reasons for the destitute state of the original Estonian dramaturgy and then view one of the aspects of the structure of Paul-Eerik Rummo's remarkable play in this context. A proficient English translation of the play byAndres Männik and Mardi Valgemäe is available in Alfreds Straumanis' anthology of Baltic plays Confrontations with Tyrrany (1977). All quotes from the play below are taken from this publication.

While any play can move beyond simple entertainment by embodying messages of universal significance, ultimately, the primary purpose of theatre is nonetheless entertainment. The origin of secular theatre for entertaining purposes, however, is usually found in religious rituals. The birth and development of classical Greek theatre from Dionysian fertility rituals is a well-known example. The same phenomenon can be traced in the development of modern 
Western theatre as well. Early in the history of the organised Catholic Church it was customary for the priests to perform simple reenactments of biblical stories in front of the altar as part of the liturgy. The ritual drama was perhaps also useful as a way of instilling biblical knowledge to the illiterate masses. These simple liturgical pieces gave rise to more complex ones. The religious pieces soon moved from the inside of the church to the outside and, eventually, priests were replaced by professional actors. This gave rise to mystery plays which in turn inspired early morality plays. All this finally developed into secular types of theatre such as Shakespeare's plays and the subsequent myriad of plays in western tradition. Thus, the important point here is that both the classical Greek theatre as well as the modern western theatre developed in its eternity out of religious practices.

We yet lack knowledge of the nature of the ritual re-enactments of the pre-Christian Estonians. While we compile certain facts about the various facets of Estonian life prior to the conquest and final capitulation to foreign invaders in 1227 from contemporary chronicles, but there is no information available on the rituals of Estonians. We can only compare the extant traditions of the Estonians and other Finno-Ugric peoples, and specualte on that. We can presume, for example, on the grounds of the extant materials collected from the Karelians, that some sort of bear cult may have been practiced in early Karelian folk religion. The lively and extensive ritual drama refers to the Khanty Bear Wake. The Khanty are quite distant linguistic relatives of the Estonians and Karelians. Today they live primarily on the coasts of the Ob River in Western Siberia and they were the last of the Finno-Ugrians to be converted to Christianity (only in the eighteenth century). This fact helps to explain why pre-Christian elements have been so well preserved in their traditions.

Whatever the nature of ritual drama among the pagan Estonians was, it was almost totally wiped out by the eager Christian missionaries determined to save the eternal souls of the native population - with force if necessary. The Estonians eventually accepted Christianity. Certain elements of pre-Christian beliefs etill survived and were in many cases incorporated into Christian rites. Remnants of an earlier time have survived, such as the sleighing down 
the slopes, a form of sympathetic magic, accompanying the rituals associated with Christian Shrovetide or St. John's Day's customs. Both are heavily imbued with elements clearly deriving from preChristian fertility rites. Pre-Christian dramatic elements have also survived in several wedding and mumming rituals. Nuptial rites have their roots in fertility rites. Mumming was a ritual dressing in disguises and other costumes accompanied by wandering from door to door begging for alms. It is a popular practice today as well. Mumming has its origins in fertility rituals as well as in ancestor worship. Other pre-Christian rites were also sporadically preserved, but have remained practically undeveloped. But such rituals associated with pre-Christian fertility rites are not theatre in the common sense of the word, however strong the dramatic element may be.

Due to the historical process in the eastern littoral region of the Baltics, the native population found itself nominally Christian, but in reality excluded from the church rule. While natives theoretically might have become priests, all evidence points to the fact that the majority of the priests and later Lutheran pastors were members of the ruling German population. Thus the organic growth necessary for the development of a dramatic tradition from church liturgy was denied to the Estonians as well. The original ritual drama was dropped and replaced by the foreign religion which rule lasted for centuries. All attempts to promote dramatic art ended due to the lack of encouragement and thereby failed to develop national theatre.

Theatrical activity in Estonia is relatively young. The first records about Shrovetide carnivals date back to the 15 th century. Presumably, some sort of theatrical element may have been present in these celebrations. Records indicate that travelling troupes performed here and there in later centuries but these were mainly German troupes performing for Germans. The earliest record of real theatre performance in Estonia date back to 1529. It was the staging of Andria by Terence by Tallinn schoolchildren and was performed in Latin. Its purpose was primarily to provide a lesson in Latin rather than entertain the audience. In 1784 the first amateur theatre was established in Estonia but the actors performed in German and the theatre was intended for Germans. One of the organisers was a 
well known Baltic-German writer August von Kotzebue, a prolific playwright, who was remarkably enlightened for his time. He donated the profits of his plays to the poor and for publishing literature in the Estonian language. He sponsored, for example, the publishing and free distribution of 10,000 copies of Arvelius' handbook on health, housekeeping and husbandry Joseph Ramma's Handbook for Emergencies and Aid (Ramma Josepi Hädda-ja AbiRamat). But as the Germans controlled almost everything, the native Estonians played only an insignificant part. The native theatre tradition in Estonian was established only with the encouragement and active participation of Johann Voldemar Jannsen and his daughter, the wellknown poet, Lydia Koidula by the inauguration of Vanemuine Song and Play Society (Vanemuise Laulu-ja Mänguselts) in 1865. The first Estonian dramaturgy emerged as a fully formed imitation of German theatre and was not rooted in the Estonian traditions. However, the Baltic German theatre imitated by the Estonian theatres was undoubtedly provincial and, at its best, second-rate as is the contemporary theatre reviews imply. In short, during the period of national awakening in the 19th century a relatively weak theatre tradition was artificially implanted into Estonian culture. Although it seems to have been a false start from the beginning.

A significant exception hereby is Paul-Eerik Rummo's 1969 play Cinderellagame (Tuhkatriinumäng, 1969). The play is ineresting because its structure is based on the only extant element of original drama found in Estonian native culture. This native form of drama, consisting of the three elements required in theatre - actors, conflict and audience - is found in a variety of games called song-games (laulumängud).

The song-games figured prominently in the social pastimes of the Estonian peasant until very recently. Although song-games were played outdoors, such as nukumäng (the doll game) at St. John's Day celebrations (24 June - the Christian replacement for the rituals associated with the summer solstice), the song-games were mainly played during the winter season between Martinmas (11 November) and Candelmas (2 February). One of the popular names for December is recorded as mängukuu (the month of games) which can only prove the fact that the playing of games was considered to 
be a particularly popular activity. After all of the outdoor activities concerning harvest were completed, life retreated indoors for the remaining dark winter period. The maidens and women of the village would gather for spinning and weaving and other needlework or perhaps just to pass time on the days when work was forbidden as on Christmas Day and the following St. Stephen's Day. Young men would also come to visit maidens on these occasions bringing liquor with them. While waiting for them, the maidens made certain that there was enough food available and the long dark evenings would be spent playing and singing. Pagan rituals, the remnants of a pre-Christian past, were often performed at these events. These evenings were usually organised in advance.

The Church tried in vain to suppress these practices as particularly pagan and licentious ones. At one period in the seventeenth century the authorities went so far as to illigimate such game evenings, but people nonetheless came secretly together. Similar to many other things that were declared unlawful it simply went underground. Many people, however, were prosecuted for organising such evenings of playing or taking part in them. The first records of old Estonian folk-songs are found in court records from such trials in the 17th century. The first recorded folk song in Estonian is found in the records of the trial against Ralli Hans from Audru Parish in Pärnu District (Southwest-Estonia), who was prosecuted for organising a play evening at his farm. This evening, certain pagan rites had been performed. Among other things he was accused of performing a ritual with a Metsik. The Metsik was a human figure made of straw. By means of certain rituals, the Metsik is believed to absorb all the evil from the surroundings and afterwards it is taken outside and left somewhere or burned. It is recorded that at this event, Ralli Hans' daughter Ello sang the following song, which is today commonly known as Needle Game Song (Nõelamängulaul). She is said to have learnt it in the neighbouring parish of Mihkli.

The Needle Game Song was recorded in court protocols in the following way (all the translations of folklore are made by the author of this paper): 
Nedko Nedko Negelcken

Nedko Negle Neiziken

Erra Nehlene kaddi

Nehla Eiß Kaddi tubediß

Nehl Kaddi nehlodes

Pißud raudine pihust.
Bob up and down sweet needle Bob up and down needle maiden The sweet needle got lost

The needle did not get lost while sleeping

The needle got lost while sewing The little steel one [got lost] from the

hand.

The comparison with a version of the same song recorded from Kuusalu Parish (the northern coast of Estonia) in 1913 can only indicate the wide popularity of the game all over the country and throughout the centuries.

Notku, notku, neulukane, Bob up and down sweet needle, notku, neula silmikäne! Ärap kadus neulukane, Bob up and down eye of the needle! The sweet needle got lost, ärap neula ja silmikäne. The needle and its eye got lost. Neul ei kadund maadessani The needle did not get lost while

kadus tüödä tehjessani. It got lost while working. sleeping

Very likely, such games were popular even before they were recorded, as they include several pre-Christian motives. Certainly they were practised until the very recent past. The success of the games relies strongly on the players' improvisational skills and a strong sense of drama necessary to participate in the game.

The games are all similar in structure. They usually consist of three parts; the first part is the song which sets the atmosphere for the game but does not contribute to the substance of the game. The second part is a dialogue between the protagonists of the game where the central conflict is established. The third part is the denouncement of the conflict, often in the form of a chase where one player (usually male) tries to catch another player (usually female) while the rest of the players try to prevent the former from achieving his goal. A typical example of a song-game is Chicken Hawk Game (kullimäng) as described and sung by Liisa Kümmel (born in 1888) from Ore village in Tori parish, Pärnu District. It was recorded by Herbert Tampere from Estonian Literary Museum in 
1961. The following is mostly based on Liisa Kümmel's version of the Chicken Hawk Game:

One of the young men plays the part of the chicken hawk. He sits in the middle of the playing area and pretends to be digging a hole or is engaged in some other unspecified activity. The other players, mostly female form a chain by holding onto the waist of the person in front. The first player is the mother hen, followed by all her chicks. The chickens enter singing the following song describing a chicken hawk who has come to stay in the village:

Kuus, kuus, kullikene, Haw, haw dear sweet hawk,

Mis siis kulli meile tulli? Why did this hawk come to visit us?

Kull otsib küla kanusid, The hawk's looking for the village

tahab talu anisida, chickens, mõisa paari partisida, kõrtsi kirju kalkunida. Kuidas kulli piakene? He wants the farm's geese, A couple of ducks from the manor, Mottled turkeys from the inn.

Nii kui mõisa mõõduvakk. Like the manor's big bushel. Kuidas kulli silmakesed? What're the hawk's little eyes like? Nii kui kulla karbikesed. Like tiny little golden boxes. Kuidas kulli nokakene? Nii kui talu taarinaga. Kuidas kulli küinekesed? Nii kui küla kaeukooku. Kuidas kulli sabakene? What's the hawk's little beak like? Like the spigot of the ale keg. What're the hawk's little nails like? Like the hook for the well.

Nii kui mõisa tuuliluuda. Like the manor house's weathervane.

By the end of the song the chicken have formed a long line in front of the chicken hawk with the mother hen facing the hawk. The conflict between the chickens and hawk develops through a dialogue similar to the one below. The more improvisation is included and the more each character/actor enters into the role, the more fun the game is for the participant and those standing around watching (after all, all people present did not necessarily participate):

Kana: Tere, tere, miis, mis auku sa kaevad? Kull: Süteauku.
Hen: Hi there, fellow! What's that hole you're digging? Hawk: A coal pit. 
Kana: Mis sa süte peale paned?

Kull: Panen paja.

Kana: Mis sa paja sisse paned?

Kull: Panen vee.

Kana: Mis sa veega tegema akkad?

Kull: Akkan kuke-kana karva võtma.

Kana: Mis kuked-kanad sulle kurja tegid?

Kull: Või ei teind? Sõid ära kõik isanda oad, emanda ernid, neitsi läätsid, toapoisi tubakad, seapoisi sibulad ja karjapoisi kaptsad!

Kana: Noo, kus sa siis isi olid?

Kull: Metsas aida tegimas.

Kana: Kus naine-lapsed olid?

Kull: Teibid kätte andmas.

Kana: Kui pikk sii aid olli? Kull: Siit senna.

Kana: Kui kõrge?

Kull: Maast taeva.

Kana: Kui lai?

Kull: Nagu kirvelaba.

Kana: Kui tihe?

Kull: Nagu jõhvisõel.

Kana: Ah, sa valelik! Isi olid ahju peal, koorekirn olli kõhu peal, konnareis olli pius, kastsid konnareit koore
Hen: Watcha gonna put on the coal pit?

Hawk: Gonna put a pot.

Hen: Watcha gonna put in the pot?

Hawk: Gonna put some water.

Hen: Watcha gonna do with the water?

Hawk: Gonna pluck the hens and roosters.

Hen: What did the hens and roosters do?

Hawk: They ate up all the master's beans, the mistress' peas, the maiden's lentils, the kitchen boy's tobacco, the swineherd's onions and the shepherd's cabbages.

Hen: and where were you all this time?

Hawk: In the forest, making a fence.

Hen: And your wife and kids?

Hawk: They were handing me the pickets.

Hen: How long was this fence?

Hawk: From here to there.

Hen: How high?

Hawk: Up to the sky.

Hen: How wide?

Hawk: Like the blade of an axe.

Hen: How tightly spaced were the pickets?

Hawk: Like a horsehair sieve.

Hen: You liar! You were sitting on the stove with a jug of cream on your belly and a frog's leg in your fist. You were dipping the frog's leg 
sisse ja tõmmasid läbi suu

limps ja limps.

Kull: Kui sa sedasi edasi

räägid ma söön su lapsed

ära! in the cream and pulling it through your mouth, smack, smack. Hawk: If you keep this talk up I'll eat up your kids!

Upon this threat the mother hen demands to know which of her chicks the hawk is going to eat up. The first chick behind the mother extends her leg out from behind its mother for the hawk to look at. The hawk rejects this one. This is repeated down the row with each chick in turn showing her leg and the hawk rejecting her until the very last chick shows her leg. This is the one that the hawk wants and he tries to catch her. Meanwhile the other chicks and their mother, without letting go of one another must prevent the hawk from catching the chick. Once the hawk has caught the chick or she has managed to escape, one round of the game is finished. It can be repeated with new players or some other game will be played.

In this game the three parts are quite distinctive. The song with its vivid description of the hawk sets a certain atmosphere but otherwise has no relevant part in the conflict or its resolution. The dialogue reveals the relationship between the hawk and the chickens and justifies the aggression of the hawk against the chickens. Finally, the chase scene attempts to somehow resolve the original conflict. In various song-games, all these parts do not necessarily need to be as clearly developed as they are in this game, nonetheless the general features are usually always present.

These song games ceased being popular forms of entertainment at the end of the 19th century. However, the Estonian intelligentsia in the late 1960s must have been aware of their existence despite the fact that they were no longer performed. A collection of old Estonian folk-songs edited by the folklorist and musicologist Herbert Tampere was published in 1958, only 10 years prior to Rummo's play. Most Estonians were familiar with this collection. We can assume that Rummo knew about the song games.

Now if we look at Paul-Eerik Rummo's play, we can perceive a remarkable structural similarity to the song-games. All of the component parts of the game are present, also the fact that the title of 
the play suggests its affinity to the song-games is no coincidence. All such games are called "game" preceded by a determiner, such as laevamäng (Ship Game), kassimäng (Cat Game), väravamäng (Gate Game), etc. Just as the Chicken Hawk Game is a game that revolves somehow around a chicken hawk, Rummo's play is a game that somehow revolves around Cinderella.

Rummo's play begins where the original Cinderella fairytale left off. After nine years of marriage, the Prince begins to have doubts about the Cinderella. When the play opens, it is February and the Prince and Cinderella are on their way to the yearly visit to Cinderella's old home. The Prince, however, secretly leaves his entourage and arrives before others early in the morning only to discover that there is another Cinderella in the kitchen. The Kitchen Cinderella's foot seems to fit the "Cinderella Slipper" that the Prince has managed to bring along. But it turns out that the Palace Cinderella (the Prince's wife) had secretly substituted the original slipper with a cheap imitation. The Prince also encounters two stepsisters who both in their own way try to lure the Prince. The Prince's dilemma is which of these four is the real Cinderella, his wife, the drudge in the kitchen who calls herself Cinderella or one of the two step-sisters. Conversations with the Master, presumably Cinderella's father, prove to be inconclusive. The Prince's frantic and ultimate encounter with the stepmother, called the Mistress in the paly, a "monumental matron" in a wheelchair, reveals that he is merely one Prince among many, all of whom are married to Cinderellas. All of the Cinderellas in turn are merely the agents of the Mistress. The Mistress cannot even remember which of the Cinderellas that she has sent out as a consort to some Prince may have been the original Cinderella.

Rummo's multi-faceted work exhibits a clear and complete connection to original Estonian drama embodied by song-games. This adds an additional layer to an already outstanding play. The three structural elements of the song-game are clearly distinctive in the structure of the play. Let us discuss these below.

The song element is subtly included in the opening scene of the play in what is in fact an inner monologue of the Prince. It is a rambling monologue interspersed with snatches of song sung by the Kitchen Cinderella. It has no real connection with the rest of 
the play which could easily exist on its own. But it does add a certain atmosphere to the play with its description of February and the bleakness.

The Prince has just been let in the kitchen by a Cinderella. It is only five a.m. and the Prince has had to get up much earlier to get ahead of the others. He looks at his pocket watch and begins to ponder on the season:

(CINDERELLA, on her part, gets more and more deeply in what she is doing and soon, without particularly developing a melody, begins to sing, while paying no attention to the PRINCE.)

PRINCE: [...] What a storm! February, February! Can't see the tip of your nose, but you must keep moving. Hungry wolves watch and wait beside the road... Exactly nine years ago it was February, too.

CINDERELLA (singing to herself): Exactly nine years from now it will be February, too.

PRINCE (continues by himself; his observation pauses are not determined by CINDERELLA'S singing, which he does not even seem to notice): Push on! Downwind? That's too much to ask for. Then at least let it be into the wind! Oh, no! First it whips from here, then from there. It lashes against one cheek, then under the other side of your coat, then it coils your body like a vine. February, February! Wolves scent you; (Observation pause.) you, hungry, scent the thaw; you can scent the thaw through this cacophonic fury. The wolves stalk after you, and you stalk after hope, hoping that the storm will cover the old tracks. Exactly nine years ago it was February, too.

CINDERELLA (as before): Exactly nine years from now it will be February, too.

PRINCE (as before): The thaw, the thaw. Where can it be? It has to come. Let the year be what it will, February is always the same. You can taste its rage. It taste of hope. Just walk and breathe; you can taste that soon all this will crack apart, that soon all these roads now cloaked with snow (Observation pause.) - stalking and cracking roadbanks - and the wolves' starved cadavers will crack on the road and on the roadbanks. The thaw! You run around as if drunk. How everything drips with joy!... (Quite tired by now.) How everything oozes and drips 
and splashes and sloshes... how wet the world is then; there isn't a dry spot on your body... you go to the fire, wanting heat... some go home, some to the pub, some to the royal castle... (Nodding off to sleep)... home castle, or royal pub... works wet.... (Talking in his sleep)... rusty... workhouses... royal works... (The PRINCES sleeps. Continuing to hum, CINDERELLA looks up from her activity for the first time and throws a fleeting glance at the PRINCE, then at her work. She leans back in order to see better, falls on her backside. The PRINCE awakens, jumps up.)

The short passages at the very beginning of the play are of a totally different nature from the main body of the play. One cannot help but notice the deep lyrical quality of the monologue which is not found in the Prince's other speeches. Moreover, nothing in these lines adds anything to the movement of the play itself. The Prince's comments "Exactly nine years ago it was February, too" followed by Cinderella's "Exactly nine years from now it will be February, too" is like a refrain woven into the text. This is further emphasised by Cinderella's tuneless hum that accompanies the whole monologue. The song ends when the Prince abruptly wakes up again.

From this point on, the Prince's dialogues with other characters are attempts to work out what is happening in the world around him. The central conflict is revealed through the ensuing dialogues between the Prince and the other characters of the tale. I do not need to comment on this middle section since in its very nature it is the parallel of the dialogue in the song-games. It provides the dramatic body of both the games as well as the play. Through the dialogues the Prince learns that all threads seem to lead to the Mistress. The Prince decides to confront her.

In the song-games the initial song and dialogue tend to be static, not imbued with any frantic movement or activity, the actual chase provides an unexpected and radical change. The same occurs in Rummo's play. If up to this point the action and emotional pitch has been relatively subdued, from this point on there is a marked change in the atmosphere of the dramatic confrontation scene between the Prince and the Mistress; the stage opens up and the Prince earnestly begins to chase the Mistress in her wheelchair around the stage. The author's stage directions at this point reveal 
how strongly the play has followed the pattern of the song games. The one-dimensional body of the play which matches the line-up of participants in the song-games; the chickens in a line in front of the hawk for example, all of a sudden becomes three-dimensional:

PRINCE: No, don't go away. I must find out... I must at least hear what you have to say.

MISTRESS: I am not going anywhere. I am just moving around a bit.

(The MISTRESS rides in an illogical, unfounded pattern with unexpected turns and stops about the stage, which acquires for the first time during the play its third dimension... So far, all props have been placed in one line, fairly far downstage, and there the action has also been carried out lineally. Exaggerating slightly, one could say that up to this point the stage has been one-dimensional, because also the height of the stage has been unlit and unused and all scenery and props have been, at most, no higher than the actors. Now, during the MISTRESS' moving about, the pipes begin to move up and down at random. Both the PRINCE and the MISTRESS tire as the result of moving about. From time to time some pipe will drop between them unexpectedly like a barrier. Then the PRINCE jumps over it or crawls under it; sometimes he swings from a pipe and propels himself after the MISTRESS. After a while he learns to react more quickly to her sudden turns. In the interest of more natural play, the movement of the pipes could be different at each performance, unexpected for the actors.)

To further differentiate the chase scene from the rest of the play, the dialogue in this scene is in blank verse. The rest of the play is in regular prose. The game-like quality is further emphasised by the author's directions which require that the pipes should be dropped differently at each performance, which makes the Mistress as well as the Prince react spontaneously.

In the following chase scene, the Mistress reveals that the world is an absurd totalitarian place, where everyone is merely one of her puppets. She makes up the rules and can change them at will. The Prince, still not satisfied with the Mistress' answer and in a final desperate attempt to make the good Fairy Godmother appear, who 
would reveal the real truth, savagely beats the Kitchen Cinderella. But there no Fairy Godmother apppears. There is no real truth. Only the arrival of others signalling that it is time for the Prince to go now prevents him from punishing the Kitchen Cinderella any further. The Prince and the Palace Cinderella depart. The Mistress wins this time. Again. As always. The Mistress is left alone with the Kitchen Cinderella and the cycle is at its start. Another Prince is expected that evening and another transformation of a Cinderella takes place. Just as in the song-game, if one set of protagonists has resolved one round of the game, new characters are assigned their roles and the game begins anew. Only in the case of Rummo's play, the Mistress remains in her role for ever.

I do not want to suggest that the play's affinity with the Estonian dramatic folklore is what ensures the lasting greatness of the play. The play has merits on a large number of levels. At the same time no other original piece of Estonian dramaturgy embodies native material so successfully to the extent that Rummo's play does. Perhaps modern Estonian playwrights could use the pre-Christian elements in the Estonian folk tradition even more effectively than Rummo, so that the Estonian dramaturgy would be transformed from a mere copy of Western European traditions into something truly connected with Estonian culture.

\section{References}

Hartnoll, Phyllis 1968. A Concise History of the Theatre. London. Rummo, Paul-Eerik 1969. Tuhkatriinumäng. Loomingu Raamatukogu nr XX, Tallinn.

Rummo, Paul-Eerik 1977. Cinderellagame. (Translated by Andres Männik and Mardi Valgemäe) Confrontations with Tyranny, (Ed. by Alfreds Staumanis). Illinois.

Tampere, Herbert 1958. Eesti rahvalaule viisidega III. Tallinn.

Tampere, Herbert \& Tampere, Erna \& Kõiva, Ottilie 1970. Eesti rahvalaule ja pillilugusid. Tallinn.

Vinkel, Aarne (ed.) 1965. Eesti kirjanduse ajalugu I. Tallinn. 